\title{
Determinants of Banks' Net Interest Margins in Honduras
}

\author{
Koffie Nassar ${ }^{1}$ \\ International Monetary Fund, United States \\ knassar@imf.org \\ Edder Martinez \\ Comisión Nacional de Bancos y Seguros, Honduras \\ emartinez@cnbs.gob.hn \\ Anabel Pineda \\ Comisión Nacional de Bancos y Seguros, Honduras \\ apineda@cnbs.gob.hn
}

\begin{abstract}
This paper analyzes the determinants of banks' net interest margins in Honduras during the years 1998 to 2013 - a period characterized by increasing banks' net interest margins, foreign bank participation and consolidation. In line with findings in the previous literature, we find that operating costs are the most important drivers of banks' net interest margins. We also find that competition among banks has led to higher concentration and that funding by parent banks positively impacts foreign banks' net interest margins. Together, these results suggest that banks, particularly foreign banks, are under pressure to consolidate and reduce operating costs in order to offer competitive interest margins. We conclude that further structural reforms and consolidation may lower banks' net interest margins.
\end{abstract}

JEL Classification: E43; E44; D43

Keywords: Banks' interest margins; Commercial banks; Panel corrected standard errors (PCSE).

\section{INTRODUCTION}

Over the last two decades, Honduras has implemented banking sector reforms and liberalization. Key areas of the reform have included strengthening the legal and regulatory framework, granting greater independence to the supervisory agency, broadening the range of

Corresponding author: International Monetary Fund, 700 19th Street, N.W., Washington, D.C. 20431, USA. Tel: +1 (202) 623-5420, e-mail: knassar@imf.org 
corrective actions, revamping the financial safety net and, more recently, introducing a monetary policy interest rate. Progress has also been made in putting in place risk-based banking supervision. While these reforms have contributed to financial deepening, banks' net interest margins have increased in recent years. On the one hand, high interest margins can contribute to strengthening bank capitalization, through transfer of profits earned by banks to their capital base. On the other hand, high interest margins are usually interpreted as an indicator of inefficiency, which adversely affects domestic real savings and investment (Brock and Rojas-Suarez; 2000). Honduras may particularly be at risk because, like all developing countries, its financial system is less developed and bank loans are the main sources of funding.

This paper examines the determinants of banks' net interest margins. There are many reasons for this study. First, anemic growth following the 2008 global financial crisis and 2009 internal political crisis have revived debate about the efficiency of financial intermediation in Honduras. Second, policymakers care about banks' interest margins because they reflect the cost of financial intermediation. Third, it is commonly thought that international banks bring new capital and greater managerial expertise, and promote efficient and competitive banking practices. Therefore, policymakers expect that, through liberalization and integration, banks' interest margins will converge to international levels. Against this background, this paper analyzes the impact of foreign bank participation.

The empirical literature on the determinants of interest margins has primarily focused on the impact of bank specific factors and macroeconomic/policy variables. Bank specific characteristics that are found to be significant determinants of banks' interest margins include: operating costs, credit activity, capital adequacy, liquidity, loan quality, credit risk, interest risk, opportunity cost of bank reserves, bank size and ownership structure. Among macroeconomic variables, inflation and real GDP growth are found to be the most important determinants. However, while there is a broad consensus that higher inflation contributes to higher interest margins, the impact of real GDP growth remains ambiguous. On the one hand, there can be a negative effect of real GDP growth on banks' interest margins due to the fact that (i) borrowers' creditworthiness and net worth deteriorates during recessions and so loan rates increase (Bernanke and Gertler; 1989) and (ii) good economic performance lowers bank defaults (Tan; 2012). On the other hand, there can be a positive effect of real GDP growth on interest margins due to the fact that demand for loans increases during cyclical upswings. For Honduras, Pineda (2010) finds operational costs and inflation as the most important bank-specific and macroeconomic determinants, respectively.

In recent years, however, there has been an increased focus on the impact of foreign bank participation on banks' interest margins. These studies include: Claessens, Demirguc-Kunt, and Huizinga (2000), Barajas, Steiner, and Salazar (2000), Martinez and Mody (2004), Fungacova and Poghosyan (2009), Poghosyan (2010), Dumicic and Ridzak (2012) and Tan (2012). The contribution of this paper is threefold. First, it builds on the previous study by Pineda (2010) and covers more recent data. Second, it controls for bank ownership. Third, it uses Beck and Katz's $(1995,1996)$ OLS-based panel corrected standard errors (PCSE) approach, which is more appropriate, given the structure of the panel dataset, than the feasible generalized lease squares (FGLS) procedure used by Pineda (2010). ${ }^{2}$

In this paper, we estimate a modified version of the cost function model by Klein (1971) and Monti (1972). We find that operating costs are the most important driver of banks' net interest margins. In addition, we find that more efficient banks have lower costs, serve the best-quality borrowers and garner greater market share. We also find that high and increasing funding by parent banks positively impacts foreign banks' net interest margins. Together, these results suggest that banks, particularly subsidiaries of foreign banks, are under pressure to consolidate and reduce

2 When comparing the performance of both estimators, the rule of thumb is that the OLS-PCSE estimator is preferable to its FGLS counterpart when (Jönsson 2005). For this study, 
operating costs in order to offer competitive interest margins. We conclude that further structural reforms and consolidation may lower banks' net interest margins.

The rest of the paper is organized as follows. Sections II and III provide a review of the related literature and the institutional background of the banking sector, respectively. Section IV presents the methodology and data. Section V discusses the empirical results. Conclusions and policy implications are presented in Section VI.

\section{LITERATURE REVIEW}

The starting point for analyzing the determinants of banks' interest margins is the seminal model by Ho and Saunders (1981). In this pioneering study, banks are assumed to be mere intermediaries between lenders and borrowers and interest margins have two basic components: the degree of competition in the banking system and the interest rate risk to which banks are exposed. This model has been criticized for not taking into account the cost structure of banks. It has since been extended to incorporate money markets (McShare and Sharpe, 1985), different types of credits/deposits (Allen, 1988), credit and interest rate risks (Angbanzo, 1997), and banks' operating costs (Maudos and Fernandez de Guevara, 2004).

While the extended model remains the workhorse of the theoretical literature, crosscountry empirical verification has proven difficult due to different institutional and regulatory environments. To circumvent these problems, some empirical studies apply a two-step procedure by first isolating the impacts of bank specific variables before proceeding to model the "pure spread" as a function of various exogenous factors not taken into consideration in the theoretical model (McShane and Sharpe, 1985; Allen, 1988; Angbazo, 1997; Saunders and Schumacher, 2000; and Brock and Rojas Suares, 2000). On the one hand, empirical results of the two-step approach generally corroborate the theoretical predictions of the extended model for industrialized countries. This has been the case in Europe (e.g., Saunders and Schumacher, 2000; Maudos and Fernandez de Guevara, 2004), the US (Angbanzo, 1997) and Australia (McShane and Sharpe, 1995; Williams, 2007).

On the other hand, empirical studies for developing countries have been more circumspect. $^{3}$ International comparison of determinants of interest margins (e.g., Demirguc-Kunt and Huizinga, 1998; Moore and Craigwell, 2000; Brock and Rojas-Suarez, 2000; Claessens, Demirguc-Kunt and Huizinga, 2001; and Gelos, 2006) go beyond the framework of the dealership model by considering a wide range of potential factors, including macroeconomic conditions, explicit and implicit bank taxation, deposit insurance regulations, financial structure, and legal and institutional indicators. More recently, Tennant and Folawewo (2009), using data for a group of 33 developing countries, find that the banking sector reserve requirement is a significant and positive determinant of interest margins. They also find that macroeconomic volatility, such as inflation, widens interest margins through its adverse impact on corporations' and households' balance sheets.

In recent years, studies have begun to explore the impact of the ownership structure of banks on interest margins. ${ }^{4}$ For developing countries, Micco, Panizza and Yanez (2007), and Fungacova and Poghosyan (2009) show that the form of bank ownership has strong influence on bank performance; La Porta (2003), and Taboada (2011) observe that locally owned banks allocate a higher proportion of their loan portfolios to low quality industries; and Demirgue-Kunt and Huizinga (1999), Claessens, Demirguc and Huizinga (2001) and Martinez and Mody (2004) show that foreign-owned banks outperform locally owned banks. Overall, these findings suggest that foreign-owned banks play an important role in developing countries.

Brock and Rojas-Suarez (2000) caution against applying this model directly to developing countries with less developed financial markets.

See Fungacova and Poghosyan (2009) and Tan (2012) for a comprehensive review of the literature. 
On Latin America, in particular, Martinez and Mody (2004) analyze the impact of increasing foreign bank participation and high concentration levels on bank's interest rate spreads using bank level data for Argentina, Chile, Colombia, Mexico, and Peru. They find that foreign banks are able to charge lower spreads relative to domestic banks, that the overall level of foreign bank participation seemed to influence spreads through its effect on administrative costs, and that banks concentration was positively and directly related to both higher spreads and higher administrative costs. To the best of our knowledge, no study has examined the impact of foreign banks on the efficiency of the banking sector in Honduras.

\section{BACKGROUND: INSTITUTIONAL STRUCTURE OF THE BANKING SECTOR}

While commercial banking in Honduras started in 1889, the first foreign-owned bank (First National Citibank of New York) entered the market in 1965 through acquisition and merger (Tábora; 2007). Following financial sector reforms, including financial liberalization and international integration, in the 1990s, subsidiaries of international banks have entered the market through acquisition and mergers (none through de novo investment). ${ }^{5}$ In the process, five banks either closed or merged, with the six largest banks accounting for 75 percent of total bank assets in 2013, compared with 10 banks in 1999. Partly as a result, despite the small size of the market in terms of population (about 7.8 million in 2011) and GDP (about US\$18.8 billion in 2013), the banking system remains moderately deep with diversified ownership. As at end-2013, 7 locally owned banks and 10 subsidiaries of foreign banks comprise the market. The subsidiaries of foreign banks have about 43 percent and 45 percent of the market in terms of deposits and loans, respectively.

The banking sector is relatively large, with total assets equivalent to 94 percent of GDP, credit to the private sector amounting to 51 percent of GDP, and broad money (M3) standing at 50 percent of GDP. The financial system comprises commercial banks, savings and loans, and finance corporations. The banking sector is the dominant player in the financial system, accounting for over 90 percent of total assets. Banks mobilize most of their resources onshore through retail and wholesale deposits - about 12 percent in demand deposit and the reminder in time and savings deposits. Dollarization of deposits is at about 31 percent of total deposits and the role of off-shore operations in financial intermediation is growing.

Honduras has a defined benefit national insurance system with total assets amounting to about 15 percent of the total financial system. About 50 percent of social security funds are placed in bank deposits - mainly in locally owned banks. These funds represent the most substantial body of long-term funds for the banking system.

Structural reforms in the banking sector, such as initiatives to improve the regulatory and supervisory framework, are ongoing. Prior to 2004, legislation allowed banks to engage in related lending to and equity participation in private companies up to the equivalent of 120 percent and 50 percent of Tier I capital, respectively. By 2007, these ratios were brought down to the limit consistent with international best practices (20-30 percent and 25 percent of Tier I capital, respectively). Overtime, solvency characteristics (Capital Adequacy Ratios) of the subsidiaries of foreign banks have also converged with their local counterparts. However, there is lack of a well-functioning interbank market, informality is a major problem, and resolution of legal cases remains slow.

Four subsidiaries of foreign banks entered the market during 2007-8. 


\section{METHODOLOGY AND DATA}

\subsection{A Basic Cost-Structure Empirical Model}

This paper estimates commercial banks' net interest margins using the cost-function model developed by Klein (1971) and Monti (1972). ${ }^{6}$ The model is based on the assumption that there is a cost function for running a bank that depends on the aggregate value of the assets being managed by the bank as well as other factors of production, such as capital and labor; i.e. Costs $=C(A ; K, L)$. Assuming that the bank maximizes profits, the income accounting identity is depicted as:

$$
\text { Profits }=\left(r_{A}-r_{D}\right)-C(A ; K, L)-\text { Provisions }- \text { NoninterestExpenses }
$$

In equation (1) profits are positive in interest earned on loans $r_{A}$, and negative in interest paid on deposits $r_{D}$, in cost of production, provisions and in non-interest expenses. In this setting, the first-order conditions for profit maximization by a competitive bank (where $d D=d A$ at the margin) is obtained as:

$$
\left(r_{A}-r_{D}\right)=\frac{\partial C(A ; K, L)}{\partial A}
$$

The first-order conditions state that a competitive bank will set the marginal cost of managing assets equal to the spread. All the other components of the accounting identity drop out because they involve inframarginal profits. If, instead, the banking system is assumed to be monopolistic, then profit maximization leads to the following condition:

$$
\left(r_{A}-r_{D}\right)=\frac{\partial C(A ; K, L)}{\partial A}+D \frac{\partial r_{D}}{\partial D}-A \frac{\partial r_{A}}{\partial A}=\frac{\partial C(A ; K, L)}{\partial A}+\frac{1}{\eta_{D}}+\frac{1}{\eta_{A}}
$$

where $\eta_{D}$ and $\eta_{A}$ are semi-elasticities of demand deposit and asset supply $\left[\eta_{D}=\frac{1}{D} \frac{d D}{d r_{D}}\right]$ and $\left[\eta_{A}=\frac{1}{A} \frac{d A}{d r_{A}}\right]$, respectively.

If, however, the banking system is characterized as oligopolistic, the spread will be a function of the number of banks in the system. Assuming a common linear cost function and Cournot behavior (see Freixas and Rochet; 2008), the spread can be expressed as:

$$
\left(r_{A}-r_{D}\right)=\frac{\partial C(A ; K, L)}{\partial A}+\frac{1}{N}\left(\frac{1}{\eta_{A}}+\frac{1}{\eta_{D}}\right)
$$

where is the number of banks. Equation (4) suggests that changes in the concentration of the banking system will affect the spread by altering the size of oligopoly profits. In other words, equation (4) rules out contestable markets and predicts that a decline in the number of banks (i.e., an oligopolistic market structure) is associated with higher spreads and marginal operating costs. ${ }^{7}$ A commonly used empirical proxy for concentration in the banking sector is the HerfindahlHirschman index (HHI). The index is obtained by squaring and summing individual bank market shares. Using HHI as a proxy for market concentration, equation (4) can be rewritten as:

$$
\left(r_{A}-r_{D}\right) \approx O C+H H I
$$

where $O C=\frac{\partial C(A ; K, L)}{\partial A}$ is operating costs.

\footnotetext{
See Freixas and Rochet (2008) for a full blown model.
}

The theory of contestable markets holds that there exist markets served by a small number of firms, which are nevertheless characterized by competitive equilibria (and therefore desirable welfare outcomes), because of the existence of potential short-term entrants. 


\subsection{Incorporating Risks}

Three fundamental risks are considered in this paper: liquidity risk, credit risk and funding risk.

\section{Liquidity Risk}

Liquidity risk is the potential losses a bank faces from interest rate mismatches. In this model, banks are not able to match up deposits with loans, owing to the endemic maturity mismatch between banks' assets and liabilities. In line with other studies in the literature, this paper uses the ratio of liquid-assets-to-total assets as a proxy for liquidity risk (LR). The rationale is that if a bank has a higher liquidity ratio, it faces lower liquidity risk, but the opportunity cost of holding higher liquidity increases, leading the bank to charge higher interest rate spreads.

\section{Credit Risk}

Credit risk concerns the probability that a borrower will default on a loan. There are two ways in which a risky loan portfolio will raise the spread: (i) intensive use of the bank's productive resources to service risky loans; and (ii) higher probability of default leading to a risk premium on the loan rate. Empirical studies of bank spreads generally use either loan write offs, the delinquent loan portfolio, or provisions for non-performing loans (NPLs) as indicators of default risk. The problem with these measures, as noted in the literature, is that they are often backward-looking (reflecting realized defaults) rather than forward-looking proxies for default risk. In line with other studies in the literature, this paper uses the lagged ratio of loan loss provisions-to-total loans and advances as a proxy for credit risk (CR).

\section{Funding Risk}

Net interest margins also depend on the way lending is funded (Funding Risk, FR) and currency risk. ${ }^{8}$ This paper uses credit-to-deposit ratio to assess the impact of banks' funding model on their net interest margins. A high and increasing loan-to-deposit ratio funded by capital inflows from abroad would lead to higher net interest margins, if the associated currency risk were adequately internalized. A sudden reversal of such inflows (a decline in the credit-to-deposit ratio) would also put pressure on banks' business models and lead to higher interest margins.

Liquidity risk (LR), credit risk (CR), and funding risk (FR) are incorporated into equation 5 to obtain a linear regression framework as follows:

$$
\left(r_{A}-r_{D}\right)=L R+O C+C R+H H I+F R
$$

\subsection{Other Considerations}

While there is no generally agreed model for analyzing the impact of macroeconomic shocks, the empirical literature has identified a number of macroeconomic variables deemed to be influential sources for variations in interest spreads. We include real GDP growth (RGDP) and CPI inflation (INFL) in the model to capture the macroeconomic environment. Thus, the equation that combines the microstructure variables with the macroeconomic determinants of interest margins is specified as:

$$
\left(r_{A}-r_{D}\right)=L R+O C+C R+H H I+F R+R G D P+I N F L
$$

\footnotetext{
8 This paper does not assess the impact of currency risk on net interest margins due to lack of readily available bank-by-bank data on the currency composition of loans and deposits.
} 
The model predictions can be summarized as follows: (i) the higher the operating costs, the higher the interest margins a bank has to charge; (ii) as market concentration rises, competition declines, and interest margins increase; (iii) higher liquidity risk, credit risk, and GDP and inflation are positively related to interest margins (Table 1).

\subsection{Empirical Estimation}

For the empirical estimation, equation 7 is rewritten to take the form:

$$
N I M_{i t}=\beta_{1} L R_{i t}+\beta_{2} O C_{i t}+\beta_{3} C R_{i t}+\beta_{4} H H I_{i t}+\beta_{5} F R+\beta_{6} R G D P_{t}+\beta_{7} I N F L_{t}+\varepsilon_{i t} \text {, }
$$

where subscripts $i$ and $t$ stand for bank and year, respectively; NIM $i t$ is the net interest margin for bank $i$ in period $t$; and $\varepsilon_{i t}$ is the error term.

In estimating equation 8 , complications relating to the error term need to be addressed. First, the observations and traits that characterize the error term for each bank are bound to be interdependent across time (autocorrelation). Second, given that the banks operate in the same industry and country, there is the possibility that the error terms will tend to be correlated across banks (contemporaneous correlation). Third, the errors will tend to have differing variances across banks (heteroskedasticity). Moreover, the errors may show heteroskedasticity because the scale of the dependent variable differs between banks (Beck and Katz; 1995). We also consider the following:

- Liquidity risk. In the Monti-Klein model, liquidity risk depends on reserves (i.e., the difference between total deposits and loans). However, given that the link between liquidity risk and net interest margin relies on the distribution of random withdrawals, the relationship may not be readily tractable. As such, the parameters or moments of such distribution and the penalty interest rate for liquidity shortage could be considered as exogenous.

- Operating cost. It is assumed that the production technology employs labor and capital, whose prices are determined in other markets. As such, operating costs (prices and levels) could be considered as exogenous.

- Credit risk. It relates default risk to a risk premium, through assumptions of its probability distribution. In a simple case, it is shown that the interest margin is independent of the characteristics of the loan. ${ }^{9}$ Thus, even when the debt-to-asset ratio of firms or households is endogenous in a General Equilibrium setting, for the purpose of this paper, it could be considered as exogenous.

- Funding risk. This variable may be considered endogenous, since it involves the quantity of loans and deposits. For this reason, in this paper, funding risk is not included in three of nine equations in order to examine its impact on the results.

Ideally, system GMM estimators of Arellano and Bover (1995) and Blundell and Bond (1998) would be more appropriate to address any potential inertia and endogeneity problems. However, given our sample size, the GMM system is not suitable as it is designed for large $\mathrm{N}$ and small $\mathrm{T}$ to provide consistent estimates. ${ }^{10}$ For these reasons, the OLS-based PCSE procedure is used to estimate Equation 8 on the grounds that this technique allows to simultaneously correct for autocorrelation, cross-equation residual correlation, and cross-sectional heteroskedasticity in order to improve parameter efficiency and generate more accurate z-statistics.

Freixas (2008) p. 268

10 Indeed, we considered system dynamic panel data estimation of various specifications of Equation 8 (assuming endogenous or predetermined risks), but both our tests for the null hypothesis of no serial correlation in the first-differenced errors at an order greater than 1 and valid overidentifying restrictions are rejected, implying model misspecification. Moreover, issues relating to managing the intractable number of instrument variables resulting from large $\mathrm{T}$ are beyond the purview of this paper. 


\subsection{Data Overview}

This section examines the statistical properties of the data and presents some stylized facts about banks' net interest margins (NIM). All the data series, except for real GDP growth and inflation, are commercial banks' quarterly data for the period 1998-2013. They are sourced from the Comisión National de Bancos y Seguros' (CNBS)'s database. The quarterly real GDP growth and inflation data are from the database of the Central Bank of Honduras. Table 1 presents a summary of the descriptive statistics of all the variables, along with their expected impact on the dependent variable (NIM). Figures 1-13 (attached) depict average variability of each variable over time.

Quarterly NIM ${ }^{11}$ are used throughout this study. Table 1 shows that NIM for subsidiaries of foreign banks have averaged 260 basis points, compared with 190 basis points for locally owned banks. While Figure 1 depicts a discernible pattern of increasing banks' NIM since 2007, Figure 2 indicates that this was solely due to the subsidiaries of foreign banks. In fact, locally owned banks' NIM decreased steadily since 1998 (Figure 3). A possible explanation is that locally owned banks rely more on non-interest income.

Moreover, a striking observation is that the dispersion (standard deviation) of the NIM for the subsidiaries of foreign banks is much larger (0.032) than that for locally owned banks (0.006). One factor that could explain this observation is that variations in net interest margins between locally owned banks and their foreign counterparts might be driven by differences in the market segments in which they operate, which in turn are likely to be the result of informational advantages that the former might have over the latter. ${ }^{12}$ In particular, it is possible that subsidiaries of foreign banks, even though they entered the market through mergers and acquisitions, have the least knowledge about the local market and so they are more likely to focus on segments that are more transparent (i.e., where it is easier to access information about borrowers).

There is also a clear difference between locally owned banks and subsidiaries of foreign banks regarding three other explanatory variables. First, subsidiaries of foreign banks tend to rely more on off-shore funding of credit than their domestic counterparts. Second, the HerfindahlHirschman Index shows that locally owned banks are highly concentrated (0.77), compared with a moderate level $(0.50)$ for the subsidiaries of foreign banks. Third, perhaps partly because of the higher market concentration, the average operating costs for locally owned banks (2.0 percent) are almost half that for the subsidiaries of foreign banks (3.3 percent). Again, this is an indication of market segmentation, which means that it may be misleading to focus on aggregates to understand the behavior of banks' net interest margins in Honduras. In other words, careful consideration needs to be given to bank-specific performance and bank ownership.

The following section employs the OLS-based PCSE regression procedure to provide more comprehensive analysis of the determinants of NIM in Honduras. As seen in Table 2, the ImPesaran-Shin unit root texts show that the w-t-bar statistics are in most cases significant at all the usual testing levels. Therefore, the null hypothesis can be rejected, indicating that the series are stationary. In addition, removing the cross-sectional mean from the series to mitigate the effects of cross-sectional correlation obtains test statistics that are significant.

\footnotetext{
11 Net interest margins are defined as the difference between a bank's interest earnings and expenses as a percentage of average interest earning assets. There are many reasons why most studies use this definition, including: (i) the data is readily available; and (ii) it forms part of a standard set of bank performance indicators which also include the return on equity (RoE), return on assets (RoA) and the cost to income ratio. The net interest margin is, however, generally seen as a better measure of banks' long-term revenue structure. Nonetheless, by definition, net interest margins do not take into consideration bank charges and income revenue associated with fees and commissions that effectively increase the costs paid by bank borrowers and reduces revenues received by depositors. An additional problem is that, by including all interest-earning assets, net interest margins may deviate significantly from the marginal spread that reflects the bank's marginal costs and revenues (Brock and Suarez; (2000). This is particularly true for Honduras, where banks hold non-interest bearing required reserves.

12 Dell'Ariccia and Marquez (2003) suggest that differences in the information available to different banks will impact whom they would lend to and what spreads they are able to charge.
} 
Table 1

Variable Description and Expected Impact on Banks' Net Interest Margins

\begin{tabular}{|c|c|c|c|c|c|c|}
\hline Variable & Notation & Description & Mean & $\begin{array}{l}\text { Standard } \\
\text { deviation }\end{array}$ & $\begin{array}{l}\text { No. Of } \\
\text { Banks }\end{array}$ & $\begin{array}{l}\text { Expected } \\
\text { impact }\end{array}$ \\
\hline \multicolumn{7}{|l|}{ All banks } \\
\hline Net Interest Margins & NIM & $\begin{array}{l}\text { Net interest income as a percentage } \\
\text { of interest earning assets }\end{array}$ & $2.2 \%$ & 0.023 & 17 & \\
\hline Liquidity Risk & LR & Liquid assets-to-total assets & $29.3 \%$ & 0.137 & 17 & Positive \\
\hline Operating costs & $\mathrm{OC}$ & Operating cost-to-total earning assets & $2.6 \%$ & 0.025 & 17 & Positive \\
\hline Credit Risk & $\mathrm{CR}$ & $\begin{array}{l}\text { Lagged ratio of loan loss provisions- } \\
\text { to-total loans and advances }\end{array}$ & $4.1 \%$ & 0.029 & 17 & Positive \\
\hline Market concentration & & Herfindahl-Hirshman Index & & & & \\
\hline Total Loans & HHI_L & Loans & 0.7 & 0.009 & 17 & Positive \\
\hline Total Deposits & HHI_D & Deposits & 0.7 & 0.010 & 17 & \\
\hline Funding Risk & FR & Credit-to-deposit ratio & $96.2 \%$ & 0.415 & 17 & $\begin{array}{l}\text { Positive/ } \\
\text { negative }\end{array}$ \\
\hline Real GDP growth & RGDP & Real GDP growth & $3.8 \%$ & 0.0297 & 17 & $\begin{array}{l}\text { Positive/ } \\
\text { negative }\end{array}$ \\
\hline Inflation & INF & End-of-year Inflation & $1.9 \%$ & 0.009 & 17 & Positive \\
\hline \multicolumn{7}{|c|}{ Subsidiaries of international banks } \\
\hline Net Interest Margins & NIM & $\begin{array}{l}\text { Net interest income as a percentage } \\
\text { of interest earning assets }\end{array}$ & $2.6 \%$ & 0.032 & 11 & \\
\hline Liquidity Risk & LR & Liquid assets-to-total assets & $31.3 \%$ & 0.179 & 11 & \\
\hline Operating costs & $\mathrm{OC}$ & Operating cost-to-total earning assets & $3.3 \%$ & 0.035 & 11 & \\
\hline Credit Risk & $\mathrm{CR}$ & $\begin{array}{l}\text { Lagged ratio of loan loss provisions- } \\
\text { to-total loans and advances }\end{array}$ & $4.1 \%$ & 0.034 & 11 & \\
\hline Market concentration & & Lagged Herfindahl-Hirshman Index & & & & \\
\hline Total Loans & HHI_L & Loans & 0.5 & 0.008 & 11 & \\
\hline Total Deposits & HHI_D & Deposits & 0.4 & 0.006 & 11 & \\
\hline Funding Risk & FR & Credit-to-deposit ratio & $99.2 \%$ & 0.551 & 11 & \\
\hline \multicolumn{7}{|l|}{ Locally owned banks } \\
\hline Net Interest Margins & NIM & $\begin{array}{l}\text { Net interest income as a percentage } \\
\text { of interest earning assets }\end{array}$ & $1.9 \%$ & 0.006 & 10 & \\
\hline Liquidity Risk & LR & Liquid assets-to-total assets & $27.6 \%$ & 0.085 & 10 & \\
\hline Operating costs & $\mathrm{OC}$ & Operating cost-to-total earning assets & $2.0 \%$ & 0.007 & 10 & \\
\hline Credit Risk & $\mathrm{CR}$ & $\begin{array}{l}\text { Lagged ratio of loan loss provisions- } \\
\text { to-total loans and advances }\end{array}$ & $4.2 \%$ & 0.024 & 10 & \\
\hline Market concentration & & Lagged Herfindahl-Hirshman Index & & & & \\
\hline Total Loans & HHI_L & Loans & 0.8 & 0.011 & 10 & \\
\hline Total Deposits & HHI_D & Deposits & 0.9 & 0.012 & 10 & \\
\hline Funding Risk & FR & Credit-to-deposit ratio & $93.7 \%$ & 0.250 & 10 & \\
\hline
\end{tabular}

Source: Authors' calculations. 
Table 2

Im-Pesaran-Shin Panel Data Unit Root Tests ${ }^{1)}$

\begin{tabular}{lcccc}
\hline \hline & \multicolumn{2}{c}{ Im-Pesaran-Shin } & \multicolumn{2}{c}{ Im-Pesaran-Shin (Demean) } \\
\hline W-t-bar & P > t & W-t-bar & P > t \\
\hline All Banks & & & & \\
Net Interest Margins & -3.51 & 0.00 & -1.55 & 0.06 \\
Liquidity Risk & -5.72 & 0.00 & -6.13 & 0.00 \\
Operating cost & -6.54 & 0.00 & -2.48 & 0.01 \\
Credit Risk & -2.85 & 0.00 & -2.65 & 0.00 \\
HHI Total Loans & 0.98 & 0.84 & -2.41 & 0.01 \\
HHI Total Deposits & -0.35 & 0.36 & -5.08 & 0.00 \\
Funding Risk & -3.19 & 0.00 & -2.81 & 0.00 \\
Real GDP & -5.30 & 0.00 & & \\
Inflation & -10.70 & 0.00 & & \\
\hline \hline
\end{tabular}

1) All variables are in levels. All regressions are augmented one lag and (excepting HHI variables) have no trend.

Source: Authors' calculations.

\section{ESTIMATION RESULTS}

We present the estimation results of Equation 8 in three steps. In the first step, we run the model on only the bank specific variables (Table 3, column 1). The second and third columns of Table 3 include dummies for subsidiaries of foreign banks and locally owned banks, respectively. In the second step, we run the model, including the macroeconomic variables, but excluding the funding-risk variable (Table 3, columns 4-6). In the third step, we run the full model (Table 3 , columns 7-9). As can be seen in Table 3, the R-squares for the three steps are practically the same, which suggests that bank-specific variables explain almost all the variability in banks' net interest margins. We note that, by controlling for funding risk, the estimated coefficients for the dummy variables are not statistically significant, which means that ownership does not matter. We proceed by analyzing the estimation results in column 7 .

As expected by the empirical model, the liquidity ratio is positively correlated with net interest margins. It is also statistically significant. This result is in tune with the literature, since banks tend to pass their liquidity risks to their clients via increased interest margins. Even though the estimated coefficient of the liquidity variable seems to be quantitatively small, it captures the positive impact of holding large amounts of excess liquidity (including low-yielding shortterm assets, required reserves, and cash in vault) on net interest margins. ${ }^{13}$ It also highlights the importance of a vibrant interbank market for operational efficiency and lower net interest margins.

13 Results not given in this paper show that required reserves are highly correlated with our liquidity ratio. 
Table 3

OLS-PCSE Panel Estimation Results

\begin{tabular}{|c|c|c|c|c|c|c|c|c|c|}
\hline & Eq. 1 & Eq. 2 & Eq. 3 & Eq. 4 & Eq. 5 & Eq. 6 & Eq. 7 & Eq. 8 & Eq. 9 \\
\hline Liquidity risk & $\begin{array}{l}0.01^{* * *} \\
(4.10)\end{array}$ & $\begin{array}{l}0.01^{* * *} \\
(4.17)\end{array}$ & $\begin{array}{l}0.01^{* * *} \\
(4.39)\end{array}$ & $\begin{array}{c}0.01^{* * *} \\
(3.26)\end{array}$ & $\begin{array}{l}0.01^{* * *} \\
(2.90)\end{array}$ & $\begin{array}{l}0.01^{* * *} \\
(3.85)\end{array}$ & $\begin{array}{l}0.01^{* * *} \\
(3.53)\end{array}$ & $\begin{array}{c}0.01^{* * *} \\
(3.52)\end{array}$ & $\begin{array}{l}0.01^{* * *} \\
(3.91)\end{array}$ \\
\hline Operating costs & $\begin{array}{l}0.46^{* * *} \\
(6.99)\end{array}$ & $\begin{array}{l}0.46^{* * *} \\
(7.04)\end{array}$ & $\begin{array}{l}0.45^{* * *} \\
(7.04)\end{array}$ & $\begin{array}{c}0.52^{* * *} \\
(9.21)\end{array}$ & $\begin{array}{l}0.50^{* * *} \\
(8.34)\end{array}$ & $\begin{array}{l}0.52^{* * *} \\
(9.26)\end{array}$ & $\begin{array}{l}0.46^{* * *} \\
(7.04)\end{array}$ & $\begin{array}{c}0.47^{* * *} \\
(7.11)\end{array}$ & $\begin{array}{l}0.46^{* * *} \\
(7.12)\end{array}$ \\
\hline Credit risk & $\begin{array}{l}0.09^{* * *} \\
(2.77)\end{array}$ & $\begin{array}{l}0.09^{* * *} \\
(2.89)\end{array}$ & $\begin{array}{l}0.09^{* * *} \\
(2.68)\end{array}$ & $\begin{array}{c}0.11^{* * *} \\
(3.93)\end{array}$ & $\begin{array}{l}0.11^{* * *} \\
(4.03)\end{array}$ & $\begin{array}{l}0.11^{* * *} \\
(3.84)\end{array}$ & $\begin{array}{l}0.08^{* * *} \\
(2.73)\end{array}$ & $\begin{array}{l}0.09^{* * *} \\
(2.93)\end{array}$ & $\begin{array}{l}0.09^{* * *} \\
(2.79)\end{array}$ \\
\hline Herfindahl-Hirschman index & $\begin{array}{l}-0.08^{* * *} \\
(-3.04)\end{array}$ & $\begin{array}{c}-0.10^{* * *} \\
(-3.13)\end{array}$ & $\begin{array}{l}-0.09^{* * *} \\
(-3.57)\end{array}$ & $\begin{array}{c}-0.07^{* * *} \\
(-2.95)\end{array}$ & $\begin{array}{c}-0.12^{* * *} \\
(-3.54)\end{array}$ & $\begin{array}{c}-0.08^{* * *} \\
(-3.20)\end{array}$ & $\begin{array}{c}-0.10^{* * *} \\
(-3.83)\end{array}$ & $\begin{array}{c}-0.12^{* * *} \\
(-3.55)\end{array}$ & $\begin{array}{c}-0.11^{* * *} \\
(-3.97)\end{array}$ \\
\hline Funding risk & $\begin{array}{c}0.004^{* * * *} \\
(3.51)\end{array}$ & $\begin{array}{c}0.004^{* * *} \\
(3.02)\end{array}$ & $\begin{array}{l}0.004 \\
(3.55)\end{array}$ & & & & $\begin{array}{l}0.004^{* * *} \\
(3.26)\end{array}$ & $\begin{array}{l}0.003^{* * *} \\
(2.70)\end{array}$ & $\begin{array}{l}0.004^{* * *} \\
(3.24)\end{array}$ \\
\hline Real GDP growth & & & & $\begin{array}{c}-0.01 \\
(-1.14)\end{array}$ & $\begin{array}{c}-0.01 \\
(-1.01)\end{array}$ & $\begin{array}{c}-0.01 \\
(-1.03)\end{array}$ & $\begin{array}{l}-0.01 \\
(-1.46)\end{array}$ & $\begin{array}{c}-0.01 \\
(-1.44)\end{array}$ & $\begin{array}{c}-0.01 \\
(-1.37)\end{array}$ \\
\hline Inflation & & & & $\begin{array}{l}0.12^{* * *} \\
(4.31)\end{array}$ & $\begin{array}{l}0.11^{* * *} \\
(4.27)\end{array}$ & $\begin{array}{l}0.12^{* * *} \\
(4.36)\end{array}$ & $\begin{array}{l}0.07^{* * *} \\
(3.03)\end{array}$ & $\begin{array}{c}0.07^{* * *} \\
(3.10)\end{array}$ & $\begin{array}{c}0.07^{* * *} \\
(3.13)\end{array}$ \\
\hline $\begin{array}{l}\text { Dummy } \\
\text { (Subsidiaries of foreign banks) }\end{array}$ & & $\begin{array}{l}0.001 \\
(1.14)\end{array}$ & & & $\begin{array}{l}0.004^{* * *} \\
(3.60)\end{array}$ & & & $\begin{array}{l}0.002 \\
(1.55)\end{array}$ & \\
\hline $\begin{array}{l}\text { Dummy } \\
\text { (Locally owned banks) }\end{array}$ & & & $\begin{array}{l}0.000 \\
(0.06)\end{array}$ & & & $\begin{array}{l}-0.001 \\
(-0.75)\end{array}$ & & & $\begin{array}{l}-0.001 \\
(-0.90)\end{array}$ \\
\hline R-square & 0.79 & 0.80 & 0.79 & 0.78 & 0.79 & 0.79 & 0.79 & 0.80 & 0.80 \\
\hline Wald test & 3523.9 & 3760.3 & 5537.6 & 3942.6 & 4194.1 & 6139.3 & 5283.2 & 5364.1 & 7564.3 \\
\hline Prob $>X^{2}$ & 0.00 & 0.00 & 0.00 & 0.00 & 0.00 & 0.00 & 0.00 & 0.00 & 0.00 \\
\hline $\mathrm{N}$ & 17 & 17 & 17 & 17 & 17 & 17 & 17 & 17 & 17 \\
\hline
\end{tabular}

1) Coefficients in parentheses represent the respective z values. ${ }^{* * * * * *}$ denotes significance at 10,5 , and 1 percent, respectively. Source: Authors' calculations.

In line with Pineda (2010), we find that operating costs are positively and significantly correlated with net interest margins. In fact, the estimated coefficient is the largest among all the explanatory variables. Operating costs are, therefore, the most important determinant of banks' net interest margins. This finding is also in line with earlier studies on developed countries ${ }^{14}$ and emerging economies. ${ }^{15}$ Three factors explain this outcome. First, we associate this result with the costs of monitoring domestic borrowers. Operating costs reflect the activities in which different banks specialize. For example, banks that focus more on retail operations usually face larger operational costs than banks that are more oriented toward wholesale markets. This is because retail operations involve the establishment of a large number of branches, equipment and personnel to serve the retail customer. These larger costs usually translate into a higher spread (Brock and Suarez; 2000). Second, deficiencies in the legal system contribute to high cost of

\footnotetext{
14 See for example Maudos and Fernandex de Guevara (2004); Valverde and Fernandez (2007); Williams (2007); and Maudos and Solis (2009).

15 See for example Demirguc-Kunt and Huizinga (1998); Claessens, Demirguc-Kunt, and Heizinga (2001); Martinez and Mody (2004); Hesse (2007); Schwaiger and Liebeg (2008); Horvath (2009); and Fungacova and Poghosyan (2009)
} 
credit. Outdated bankruptcy procedures increase the cost of asset recovery while lengthy civil procedures related to contract enforcement and adjudication of claims make credit operations riskier and costlier (IMF; 2001). Third, operating costs reflect less efficient management and inferior organizational structures. In this context, the legal infrastructure should be updated to speed up the resolution of financial claims. Banks should also be encouraged to upgrade their operational efficiency, including the development of mobile banking, in order to bring down overhead costs.

We also find that the ratio of loan loss provisions to total loans (our measure of credit risk), which is a measure of credit quality, is positively and significantly correlated with banks' net interest margins. This result suggests that structural reforms aimed at promoting prompt expedition of legal cases, making financial information on potential borrowers accessible to all banks, and good accounting standards will improve risk assessment, reduce non-performing loans, and the need for higher loan loss provisions.

Table 4

OLS-PCSE Panel Estimation Results

\begin{tabular}{|c|c|c|c|c|c|c|c|c|c|}
\hline & Eq1 & $\mathbf{E q 2}$ & $\mathbf{E q 3}$ & $\mathrm{Eq4}$ & Eq5 & Eq6 & Eq7 & Eq8 & Eq9 \\
\hline Liquidity Risk & $\begin{array}{c}0.01^{* * *} \\
(3.48)\end{array}$ & $\begin{array}{c}0.009^{* * *} \\
(3.25)\end{array}$ & $\begin{array}{c}0.012^{* * *} \\
(3.99)\end{array}$ & $\begin{array}{c}0.009^{* * *} \\
(2.86)\end{array}$ & $\begin{array}{c}0.007^{* *} \\
(2.18)\end{array}$ & $\begin{array}{c}0.013^{* * *} \\
(3.5)\end{array}$ & $\begin{array}{c}0.009^{* * *} \\
\text { (3) }\end{array}$ & $\begin{array}{c}0.008^{* * *} \\
(2.76)\end{array}$ & $\begin{array}{c}0.012^{* * *} \\
(3.54)\end{array}$ \\
\hline Operating cost & $\begin{array}{c}0.486^{* * *} \\
(7.1)\end{array}$ & $\begin{array}{c}0.49^{* * *} \\
(7.16)\end{array}$ & $\begin{array}{c}0.48^{* * *} \\
(7.11)\end{array}$ & $\begin{array}{c}0.539^{* * *} \\
(8.99)\end{array}$ & $\begin{array}{c}0.52^{* * *} \\
(8.18)\end{array}$ & $\begin{array}{c}0.529^{* * *} \\
(8.99)\end{array}$ & $\begin{array}{c}0.487^{* * *} \\
(7.14)\end{array}$ & $\begin{array}{c}0.495^{* * *} \\
(7.26)\end{array}$ & $\begin{array}{c}0.483^{* * *} \\
(7.21)\end{array}$ \\
\hline Credit Risk & $\begin{array}{c}0.083^{* *} \\
(2.32)\end{array}$ & $\begin{array}{c}0.092^{* *} \\
(2.51)\end{array}$ & $\begin{array}{c}0.088^{* *} \\
(2.36)\end{array}$ & $\begin{array}{c}0.108^{* * *} \\
(3.33)\end{array}$ & $\begin{array}{c}0.109^{* * *} \\
(3.33)\end{array}$ & $\begin{array}{c}0.113^{* * *} \\
(3.37)\end{array}$ & $\begin{array}{l}0.08^{* *} \\
(2.29)\end{array}$ & $\begin{array}{l}0.09^{* *} \\
(2.52)\end{array}$ & $\begin{array}{c}0.087^{* *} \\
(2.43)\end{array}$ \\
\hline HHI Total Loans & $\begin{array}{c}0.139^{* *} \\
(2.41)\end{array}$ & $\begin{array}{c}0.139^{* *} \\
(2.26)\end{array}$ & $\begin{array}{c}0.158^{* *} \\
(2.57)\end{array}$ & $\begin{array}{c}0.198^{* * *} \\
(3.89)\end{array}$ & $\begin{array}{l}0.112^{*} \\
(1.88)\end{array}$ & $\begin{array}{c}0.215^{* * *} \\
(3.9)\end{array}$ & $\begin{array}{l}0.093 \\
(1.63)\end{array}$ & $\begin{array}{l}0.086 \\
(1.38)\end{array}$ & $\begin{array}{l}0.107^{*} \\
(1.76)\end{array}$ \\
\hline HHI Total Deposits & $\begin{array}{c}-0.207^{* * *} \\
(-3.15)\end{array}$ & $\begin{array}{c}-0.206^{* * *} \\
(-3.1)\end{array}$ & $\begin{array}{c}-0.229^{* * *} \\
(-3.37)\end{array}$ & $\begin{array}{c}-0.276^{* * *} \\
(-4.4)\end{array}$ & $\begin{array}{c}-0.186^{* * *} \\
(-2.84)\end{array}$ & $\begin{array}{c}-0.298^{* * *} \\
(-4.52)\end{array}$ & $\begin{array}{c}-0.18^{* * *} \\
(-2.74)\end{array}$ & $\begin{array}{c}-0.176^{* *} \\
(-2.56)\end{array}$ & $\begin{array}{c}-0.192^{* * *} \\
(-2.8)\end{array}$ \\
\hline Funding Risk & $\begin{array}{c}0.004^{* * *} \\
(3.05)\end{array}$ & $\begin{array}{c}0.003^{* *} \\
(2.41)\end{array}$ & $\begin{array}{c}0.004^{* * *} \\
(3.11)\end{array}$ & & & & $\begin{array}{c}0.004^{* * *} \\
(2.84)\end{array}$ & $\begin{array}{c}0.003^{* *} \\
(2.16)\end{array}$ & $\begin{array}{c}0.004^{* * *} \\
(2.82)\end{array}$ \\
\hline Real GDP & & & & $\begin{array}{l}-0.011 \\
(-1.14)\end{array}$ & $\begin{array}{c}-0.01 \\
(-1.06)\end{array}$ & $\begin{array}{l}-0.009 \\
(-0.96)\end{array}$ & $\begin{array}{l}-0.012 \\
(-1.45)\end{array}$ & $\begin{array}{l}-0.012 \\
(-1.38)\end{array}$ & $\begin{array}{c}-0.01 \\
(-1.27)\end{array}$ \\
\hline Inflation & & & & $\begin{array}{c}0.107^{* * *} \\
(3.89)\end{array}$ & $\begin{array}{c}0.101^{* * *} \\
(3.87)\end{array}$ & $\begin{array}{c}0.117^{* * *} \\
(4.12)\end{array}$ & $\begin{array}{c}0.064^{* * *} \\
(2.78)\end{array}$ & $\begin{array}{c}0.072^{* * *} \\
(2.97)\end{array}$ & $\begin{array}{c}0.075^{* * *} \\
(3.08)\end{array}$ \\
\hline $\begin{array}{l}\text { Dummy } \\
\text { (Subsidiaries of foreign bank) }\end{array}$ & & $\begin{array}{c}0.002^{*} \\
(1.9)\end{array}$ & & & $\begin{array}{c}0.005^{* * *} \\
(3.46)\end{array}$ & & & $\begin{array}{c}0.002^{* *} \\
(2.1)\end{array}$ & \\
\hline $\begin{array}{l}\text { Dummy } \\
\text { (Subsidiaries of domestic bank) }\end{array}$ & & & $\begin{array}{l}-0.001 \\
(-0.83)\end{array}$ & & & $\begin{array}{l}-0.001 \\
(-1.31)\end{array}$ & & & $\begin{array}{l}-0.001^{*} \\
(-1.67)\end{array}$ \\
\hline R-square & 0.77 & 0.78 & 0.77 & 0.77 & 0.78 & 0.77 & 0.78 & 0.78 & 0.78 \\
\hline Wald Test & $2,959.66$ & $2,624.22$ & $4,160.39$ & $3,647.99$ & $3,055.63$ & $4,675.85$ & $4,331.55$ & $3,632.17$ & $5,384.79$ \\
\hline Prob $>\chi 2$ & 0.00 & 0.00 & 0.00 & 0.00 & 0.00 & 0.00 & 0.00 & 0.00 & 0.00 \\
\hline
\end{tabular}

1) Coefficients in parenthesis represent the respective z values., ${ }^{* *},{ }^{* * *}$ denotes significance at 10,5 and 1 percent, respectively. Source: Authors' calculations. 
Contrary to the prior assumptions of the empirical model, the estimated coefficient for market concentration is negative and statistically significant for all banks (Table 3 ). As noted in Freixas (2008), even though empirical findings derived from the Monti-Klein model cannot explain features of deposit contracts, it can be expected that market power should allow banks "to quote lower deposit rates and higher rates on loans". ${ }^{16}$ Furthermore, given that the oligopolistic version of the Monti-Kelin model relies on characteristics of credit and deposit markets, we deem it convenient to incorporate the HHI index for deposits in Equation 8 to stimulate a deeper discussion of the phenomenon of concentration and lower interest margins (Table 4). Results show that the HHI index for deposits is negative and significant, and that for loans turns positive and significant as expected, indicating that banks with market power can charge higher lending rates and offer lower deposit rates. Therefore, we conclude that the market is contestable. In other words, higher concentration is a consequence of tougher competition among banks (Boone and Weigand; 2000), especially to attract deposits. A possible rationale is that more efficient banks attract time and savings deposits, have lower costs, serve the best-quality borrowers and garner greater market share, thereby forcing less efficient banks to consolidate and reduce operating costs in order to offer competitive interest margins.

Funding risk is an important determinant of net interest margins, particularly for subsidiaries of foreign banks. We find that not controlling for funding risk makes the dummy variable for the subsidiaries of foreign banks positive and statistically significant (Table 3, column 5). In contrast, by controlling for funding risk (see column 8), we find that the estimated coefficient is positive and statistically significant, but that the estimated coefficient for the dummy variable becomes statistically insignificant. This means that high and increasing loan-to-deposit ratios, funded by parent banks, put pressure on the business models for subsidiaries of foreign banks and lead to higher interest margins. While the paper does not describe the channel behind this relationship, it could be related to transmission of shocks by parent banks to affiliates (Chava and Purnandam, 2011; Cetorelli and Goldberg, 2012a; and Cetorelli and Goldberg, 2012b). With relatively low percentage of the adult population having an account in the formal banking system in Honduras, improving access to financial services - financial inclusion-would help limit negative crossborder spillovers.

Turning to macroeconomic variables, we find that the results are mixed. As expected and in line with Pineda (2010), the estimated coefficient for inflation is positive and statistically significant, and the size is non-negligible. As stressed by Huybens and Smith (1999), inflation does exacerbate informational asymmetries and therefore leads to larger interest margins. However, similar to Pineda (2010), we find that economic growth (the business cycle) has no statistically significant impact on banks' interest margins. This finding suggests that banks are not adequately pricing intrinsic risks of projects and so are not allocating resources efficiently (Rajan and Zingales, 1998).

\section{CONCLUSIONS AND POLICY IMPLICATIONS}

This study provides empirical evidence on the determinants of banks' interest margins in Honduras. To this end, we specify an empirical model which constitutes an extension of the cost function model developed by Klein (1971) and Monti (1972).

As predicted by the empirical model, all the explanatory variables, except for bank concentration, real GDP growth and bank ownership, have the expected effect on banks' net interest margins. We find that operating costs are the most important determinant of banks' interest margins. In addition, we find that high provisions for nonperforming loans and liquidity ratio

16 Freixas (2008) p. 81. 
get translated into high net interest margins. We also find that credit-to-deposit ratio positively impacts banks' net interest margins. However, contrary to the prior assumptions of the model, the banking concentration variable is negative and statistically significant, indicating that tougher competition has led to higher concentration and lower net interest margins. Beyond bank-specific variables, we find that inflation (uncertainty in the macroeconomic environment facing banks) appears to be an important determinant of high interest margins. However, real GDP growth has no statistically-significant impact on banks' net interest margins. Finally, we find that ownership does not matter if the transmission of funding risks from parent banks is limited.

These results suggest that banks, particularly subsidiaries of foreign banks, are under pressure to consolidate and reduce operating costs in order to offer competitive interest margins. To allow banks to upgrade their operational efficiency, the authorities could implement structural reforms aimed at supporting the information environment (such as promoting credit information-sharing systems and collateral registries) and promoting international accounting standards, independent and credible auditing of borrowers (private companies), prompt adjudication of legal cases, mobile banking, financial inclusion and a vibrant interbank market. At the same time, maintaining macroeconomic stability, such as low and stable inflation, will lower information asymmetries. Together, these measures will allow banks to adequately price intrinsic risk and improve the efficiency of resource allocation.

\section{Acknowledgements}

The authors would like to thank Lisandro Abrego, Pablo Druck, Bogdan Lissovolik, Carlos Medeiros, and staff of the Comisión Nacional de Bancos y Seguros for helpful comments. The authors remain responsible for all remaining errors and omissions.

\section{References}

Allen, L., 1988, “The determinants of Bank Interest Margins: A Note," Journal of Financial and Quantitative Analysis, 23(2), pp. 231-35.

Angbanzo, L., 1997, "Commercial Bank Net Interest Margins, Default Risk, Interest-Rate Risk, and Off-Balance Sheet Banking," Journal of Banking and Finance, 21, pp. 55-87.

Arellano, M., and O. Bover 1995, “Another Look at the Instrumental-Variable Estimation of Error-Components Models," Journal of Econometrics, Vol. 68 (1), pp. 29-51.

Barajas, A., R. Steiner and N. Salazar, 1999, “Interest Spreads in Banking in Colombia 1974-96,” IMF Staff Papers, 46, pp. 196-224.

Beck, N., and N. Katz, 1995, "What to Do (and Not to Do) with Time-Series Cross-Section Data," American Political Science Review, Vol. 89, pp. 634-47.

Beck, N., and N. Katz, 1996, "Nuisance vs. Substance: Specifying and Estimating Time-Series-Cross-Section Models, Political Analysis, 6, pp. 1-36.

Bernanke, B.S., and M. Gertler, 1989, “Agency Costs, Net Worth, and Business Fluctuations,” American Economic Review, 79, pp. 14-31.

Blackwell, J. L. III, 2005, "Estimation and Testing of Fixed-Effect Panel-Data Systems," The Stata Journal, 5, Number 2, pp. 202-7.

Blundell, R. W., and S. R. Bond, 1998, "Initial Conditions and Moment Restrictions in Dynamic Panel Data Models," Journal of Econometrics, Vol. 87, pp. 115-143.

Bonin, J., I. Hasan, and P. Wachtel, (2005), "Privatization matters: bank efficiency in transition Countries," Journal of Banking \& Finance, 29 (1), pp. 31-53.

Boone, J., and J. Weigand, 2000, "Measuring Competition in the Dutch Manufacturing Sector: How are Cost Differentials Mapped into Profit Differentials," CPB Working Paper No. 131, Den Haag

Brock, P., and L. Rojas-Suarez, 2000, "Understanding the Behavior of Bank Spreads in Latin America," Journal of Development Economics, Vol. 63 (1), pp. 113-34. 
Brock, P., and H. Franken, 2002, "Bank Interest Margins Meet Interest Rate Spreads: How Good is Balance Sheet Data for Analyzing the Cost of Financial Intermediation?" available at http://scid.stanford.edu/people/ mckinnon_program/BrockV2/pdf.

Brock, P., and H. Franken, 2003, "Measuring the Determinants of Average and Marginal Bank Interest Rate Spreads in Chile, 1994-2001. Available at www.econ.washington.edu/user/plbrock/ChileSpreads091603.pdf.

Carbo-Valverde, S. and F. Rodriguez-Fernandez, 2007, "The Determinants of Bank Margins in European Banking," Journal of Banking and Finance, 31, pp. 2043-63.

Cetorelli, N., and L. Goldberg, 2012a, "Banking Globalization and Monetary Transmission,” Journal of Finance, 67, pp. 1811-43.

Cetorelli, N., and L. Goldberg, 2012b, "Liquidity Management of U.S. Global Banks: Internal Capital Markets in the Great Recession," Journal of International Economics, 88(2), pp. 299-311.

Chava, S., and A. Purnanandam, 2011, "The Effect of Banking Crisis on Bank-Dependent Borrowers," Journal of Financial Intermediation, 19, pp. 1-25.

Chirwa, E. and M. Mlachila, 2004, "Financial reforms and interest rate spreads in the commercial banking system in Malawi, IMF Staff Papers, 51, pp. 96-122.

Claessens, S., A. Demirguc-Kunt, and H. Huizinga, 2001, "How Does Foreign Entry Affect Domestic Banking Markets," Journal of Banking and Finance, 25, pp. 891-911.

Dell'Ariccia, G., and R. Marquez, 2003, "Information and Bank Credit Allocation," Available at SSRN: http://ssrn. com/abstract $=431300$.

Demirguc-Kunt, A., and H. Huizinga, 1998, "Determinants of Commercial Bank Interest Margins and Profitability: Some International Evidence,” Policy Research Working Paper, WPS1900, (Washington: World Bank).

Demirguc-Kunt, A., and L. Laeven, and R. Levine, 2003, "The Impact of Bank Regulations, Concentration, and Institutions on Bank Margins," mimeo, (Washington: The World Bank).

Dumicic, M., and T. Ridzak, 2012, "Determinants of Banks' Net Interest Margins in Central and Eastern Europe," Financial Theory and Practice, Croatian National Bank.

Financial System Stability Assessment (FSSA) for Honduras, 2009, SM/09/21, (Washington: International Monetary Fund).

Freixas, X., and J. Rochet, 2008, Microeconomics of Banking, $2^{\text {nd }}$ Edition, Massachusetts Institute of Technology, The MIT Press.

Fungacova, Z., and T. Poghosyan, 2009, "Determinants of Bank Interest Margins in Russia: Does Bank Ownership Matter?" BOFIT Discussion Papers 22.

Gelos, R. G., 2006, "Banking Spreads in Latin America," IMF Working Paper No. WP/06/44.

Hesse, H., 2007, "Financial Intermediation in the Pre-Consolidation Banking Sector in Nigeria," World Bank Policy Research Working Paper 4267.

Hicks, A., 1994, "Introduction to Pooling," in T. Janoski and A. Hicks (edited by), The Comparative Policy Economy of the Welfare State, Cambridge University Press.

Ho, T., and A. Saunders, 1981, "The Determinants of Bank Interest Margins: Theory and Empirical Evidence," Journal of Financial and Quantitative Analysis, 16(4), pp. 581-600.

Holton, S., R. Kelly, R. Lydon, A. Monks, and N. O’Donnell, 2013, “The Impact of the Financial Crisis on Banks' Net Interest Margins," Economic Letter Series, Central Bank of Ireland.

Horvath, R., 2009, "The Determinants of the Interest Rate Margins of Czech Banks," Czech Journal of Economics and Finance, 59(2), pp. 128-36.

Huybens, E. and Smith, B. (1999). "Inflation, financial markets, and long-run real activity," Journal of Monetary Economics, 43, pp. 283-315.

IMF (2001), Hoduras-Selected Issues, SM/01/286, (Washington: International Monetary Fund).

Jönsson, K., 2005, “Cross-Sectional Dependency and Size Distribution in a Small-sample Homogeneous Panel-Data Unit Root Test," Oxford Bulletin of Economics and Statistics, Vol. 63, pp. 369-92.

Klein, M., 1971, “A Theory of the Banking Firm,” Journal of Money, Credit and Banking, 3, pp. 205-18.

Martinez, M. S., and A. Mody, (2004), "How Foreign Participation and Market Concentration Impact Bank Spreads: Evidence from Latin America, Journal of Money Credit and Banking, 36 (3), pp. 511-37.

Maudos, J., and J. Fernandez de Guevara, 2004, "Factors Explaining the Interest Margin in the Banking Sectors of the European Union," Journal of Banking and Finance, 28, pp. 2259-81.

Maudos, J., and L. Solis, 2009, “The Determinants of Net Interest Income in the Mexican Banking System: An Integrated Model," EC Working Paper Series No. 2009-05.

McShane, R., and I. Sharpe, 1985, “A Time Series-Cross Section Analysis of the Determinants of Australian Trading Bank Loan-Deposit Interest Margins: 1962-1981,” Journal of Banking and Finance, 9(1), pp. 115-36.

Micco, A., U. Panizza, and M. Yanez, 2007, Bank Ownership and Performance: Does Politics Matter?" Journal of Banking and Finance, 31, pp. 219-41.

Mody, A., 2009, "From Bear Stearns to Anglo Irish: How Eurozone Sovereign Spreads Related to Financial Sector Vulnerability," IMF Working Paper No. WP/09/108. 
Monti, M., 1972, "Deposit, Credit, and Interest Rate Determination under Alternative Bank Objectives," In Mathematical Methods in Investment and Finance, ed. G.P. Szego and K. Shell. Amsterdam: North-Holland.

Moore, W., and R. Craigwell, 2000, "Market Power and Interest Rate Spreads in the Caribbean," Paper Presented at the XXXII Annual Monetary Studies Conference, Kingston, Jamaica.

Pineda, D., 2010, "Determinantes del Spread Bancario en Honduras," Banco Central de Honduras, UIE/DI-003/2010.

Podestà, F., 2000, "Recent Developments in Quantitative Comparative Methodology: The Case of Pooled Time Series Cross-Section Analysis, DSS Papers SOC 3-02.

Poghosyan, T., 2010, "Re-examining the impact of foreign bank participation on interest margins in emerging markets," Emerging Markets Review, Vol. 11, Issue4, pp. 390-403.

Rajan, G.R., and L. Zingales, 1998, "Which Capitalism? Lessons from the East Asian Crisis," Journal of Applied Corporate Finance, Vol. 11, No. 3, Fall 1998.

Saunders, A., and L. Schumacher, 2000, "The Determinants of bank interest margins: An International study," Journal of International Money and Finance, Vol. 19, Issue 6, pp. 813-32.

Schwaiger, M. and D. Liebeg, 2008, "Determinants of Bank Interest Margins in Central and Eastern Europe,” OeNB Financial Stability Report, Austrian National Bank.

Sengupta, R., 2007, "Foreign entry and bank competition, Journal of Financial Economics 84, pp. 502-28.

Tábora, M., 2007, “Competencia y regulación en la Banca: caso de Honduras," CEPAL, Unidad de Comercio Internacional e Industria. Serie Estudios y Perspectiva, No. 91. Noviembre (Mexico).

Tan, T.B.P. (2012), "Determinants of Credit Growth and Interest Margins in the Philippines and Asia," IMF Working Paper 12/123 (Washington: International Monetary Fund).

Tennant, D. and A. Folawewo, 2009, "Macroeconomic and Market Determinants of Banking Sector Interest Rate Spreads: Empirical Evidence from Low- and Middle-Income Countries," Applied Financial Economics, Vol. 19, Issue 6, pp. 489-507.

Williams, B., 2007, "Factors Determining Net Interest Margins in Australia: Domestic and Foreign Banks," Financial Markets, Institutions and Instruments, 16(3), pp. 145-65. 


\section{ANNEX: Attachments}

\section{Figure 1}

Honduras: Banks’ Net Interest Margins (In percent)

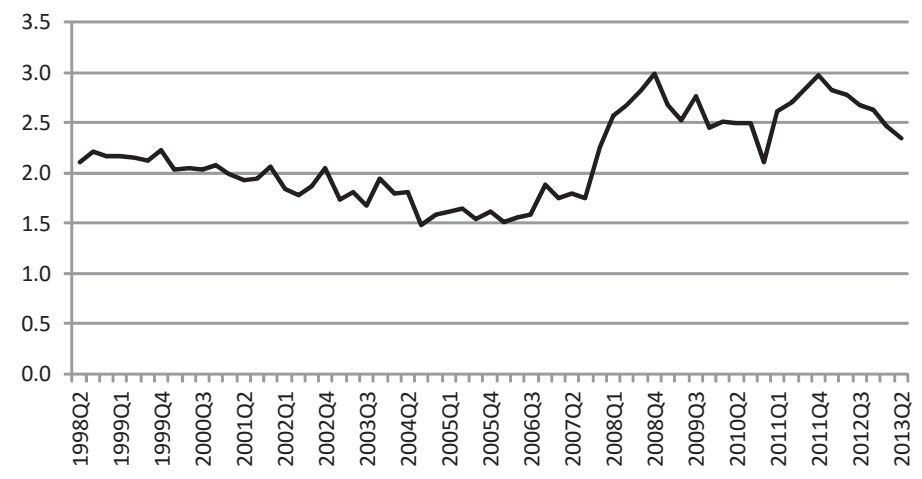

Source: CNBS.

Figure 2

Honduras: Subsidiaries of Foreign Banks' Net Interest Margins (In percent)

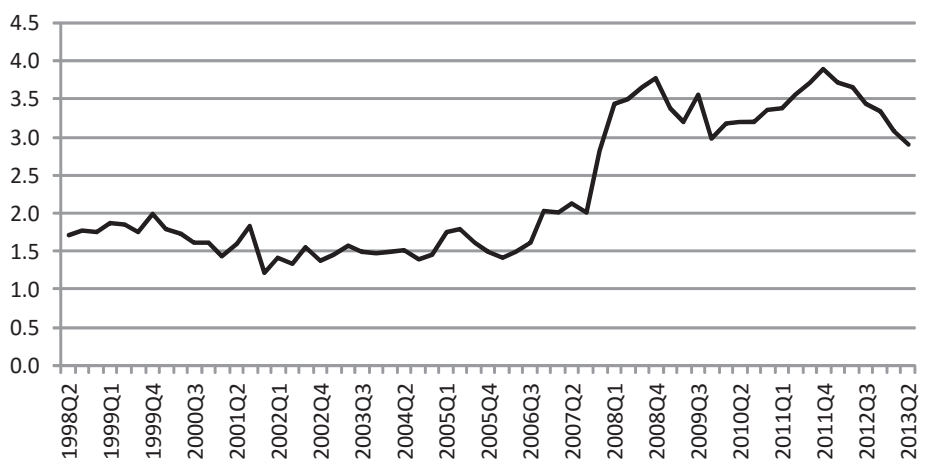

Source: CNBS

Figure 3

Honduras: Locally Owned Banks' Net Interest Margins (In percent)

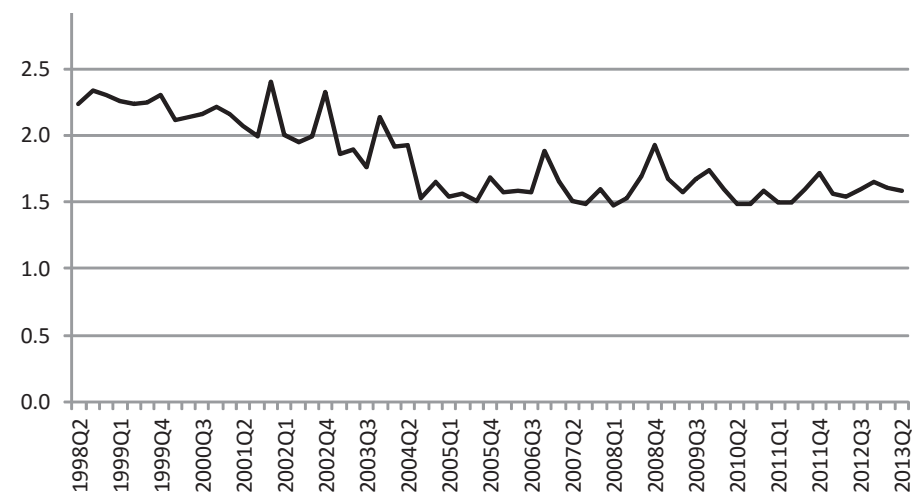

Source: CNBS 


\section{Figure 4}

Honduras: Banks' Interest Income and Interest Expenditure

(In percent of interest earning assets)

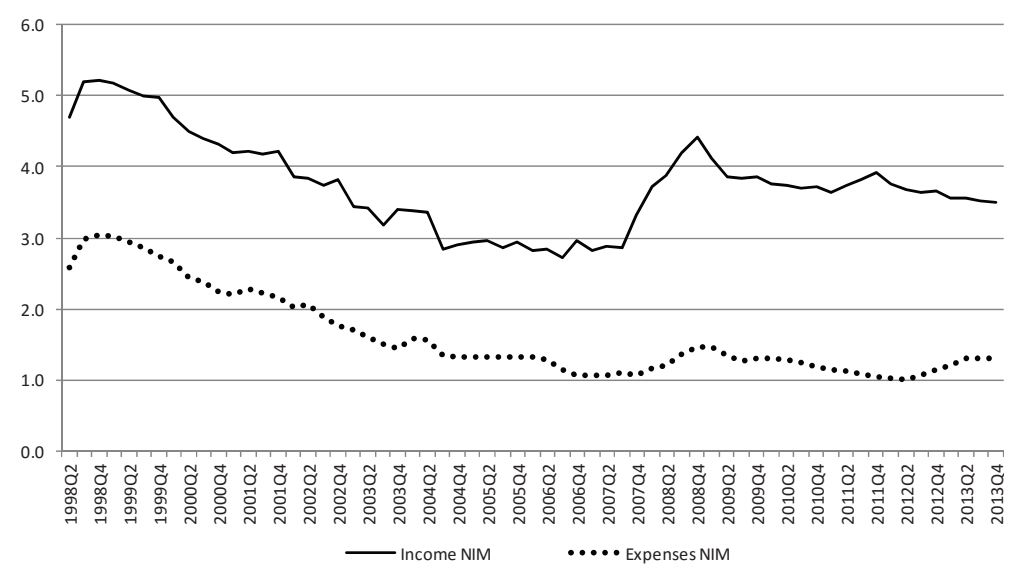

Source: CNBS.

\section{Figure 5}

Honduras: Subsidiaries of Foreign Banks' Interest Income and Interest Expenditure (In percent of interest earning assets)

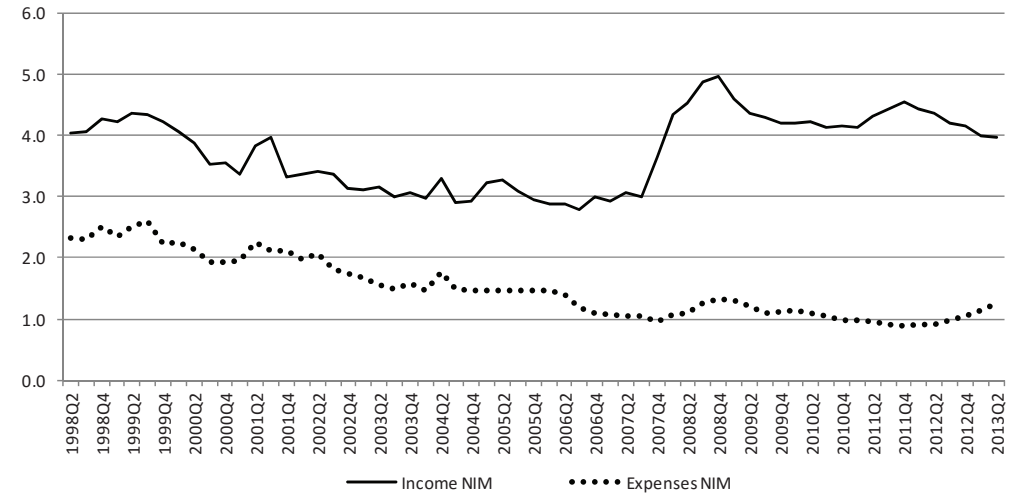

Source: CNBS

\section{Figure 6}

Honduras: Locally Owned Banks' Interest Income and Interest Expenditure (In percent of interest earning assets)

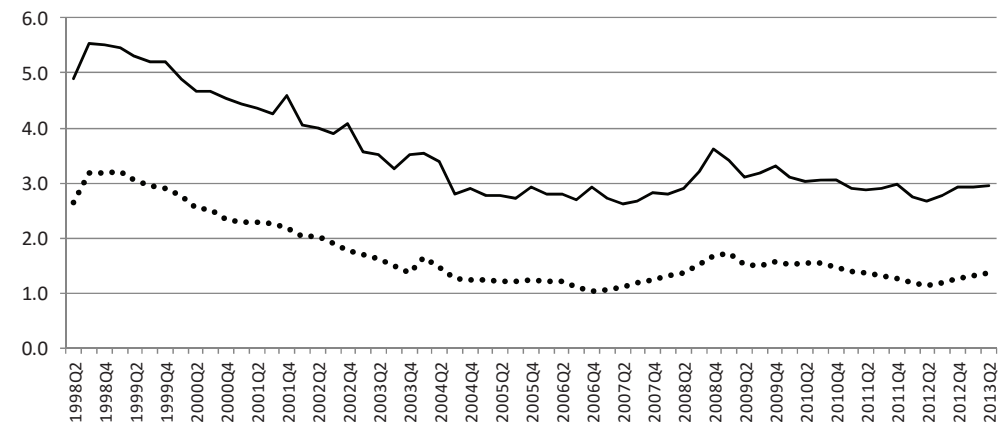

_ Income NIM $\quad$ _..... Expenses NIM

Source: CNBS 
Figure 7

Honduras: Banks’ Liquidity Ratio (In percent)

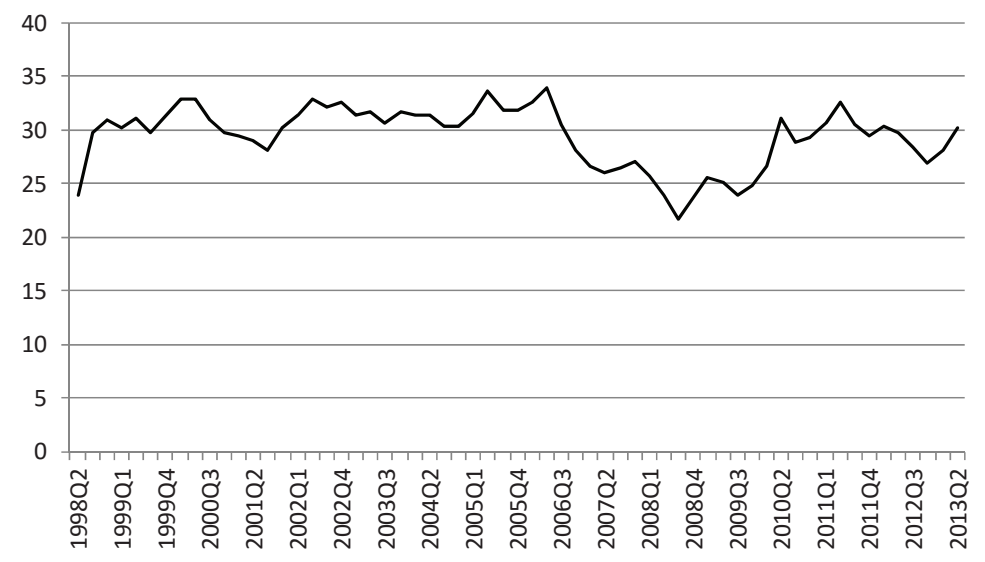

Source: CNBS

Figure 8

Honduras: Banks’ Operational Costs (In percent)

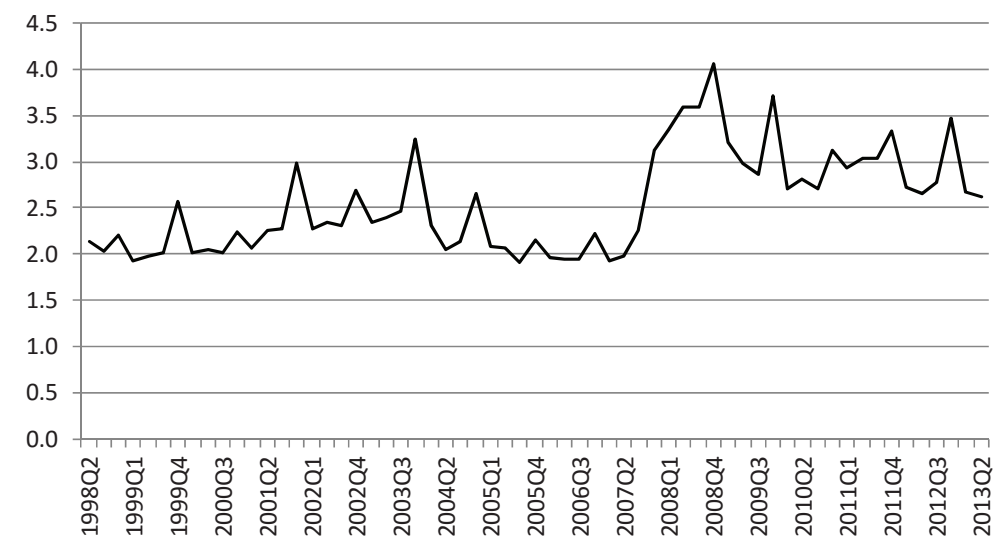

Source: CNBS

Figure 9

Honduras: Subsidiaries of Foreign Banks' Operational Costs (In percent)

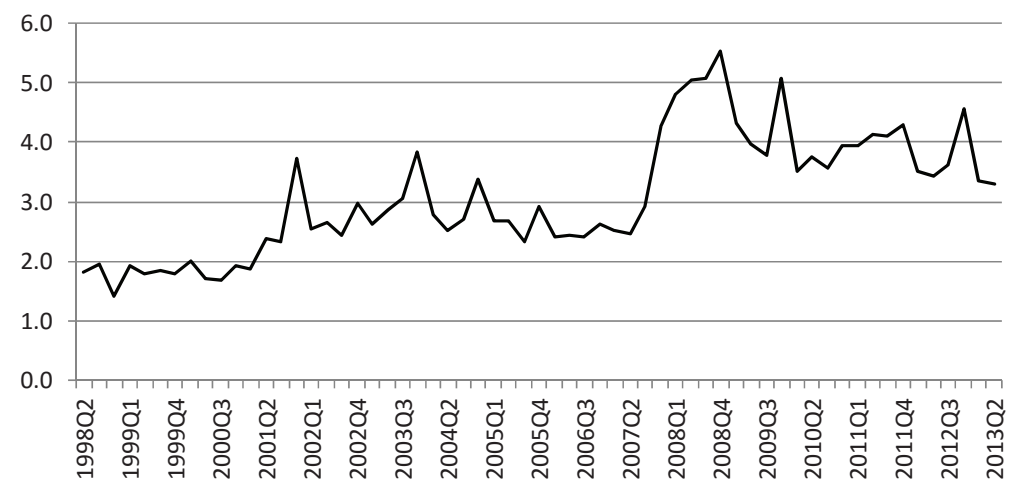

Source: CNBS 
Figure 10

Honduras: Locally Owned Banks’ Operational Costs (In percent)

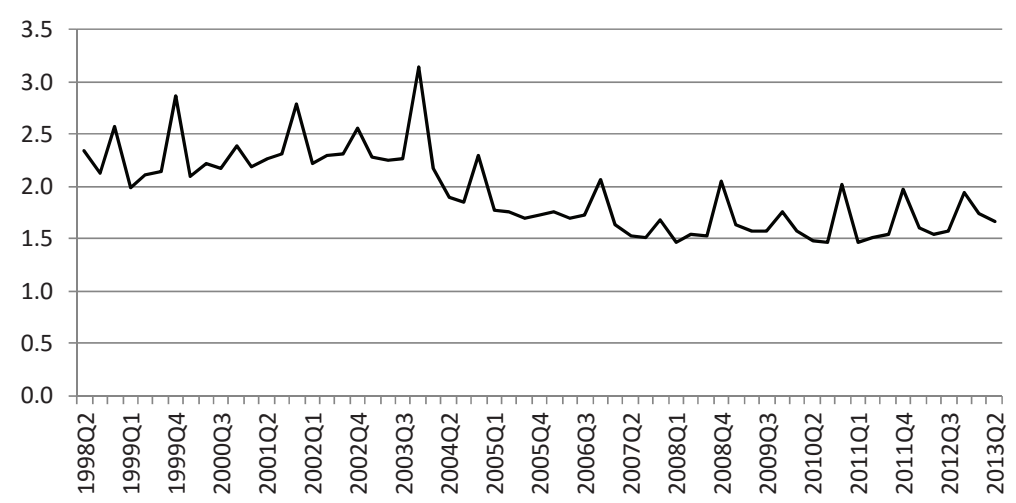

Source: CNBS.

Figure 11

Honduras: Banks’ Credit Risks (In percent)

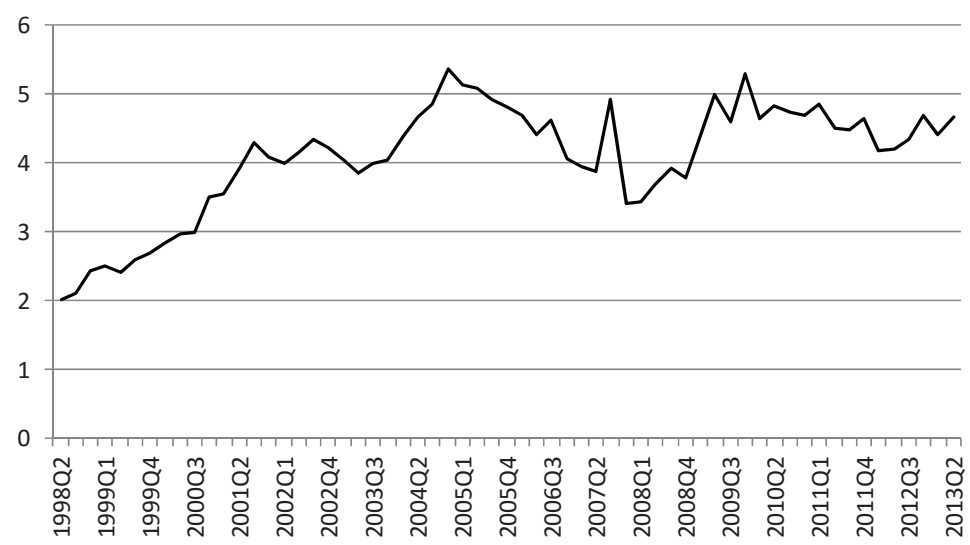

Source: CNBS.

\section{Figure 12}

Honduras: Banks' Herfindahl-Hirschman Index (In percent)

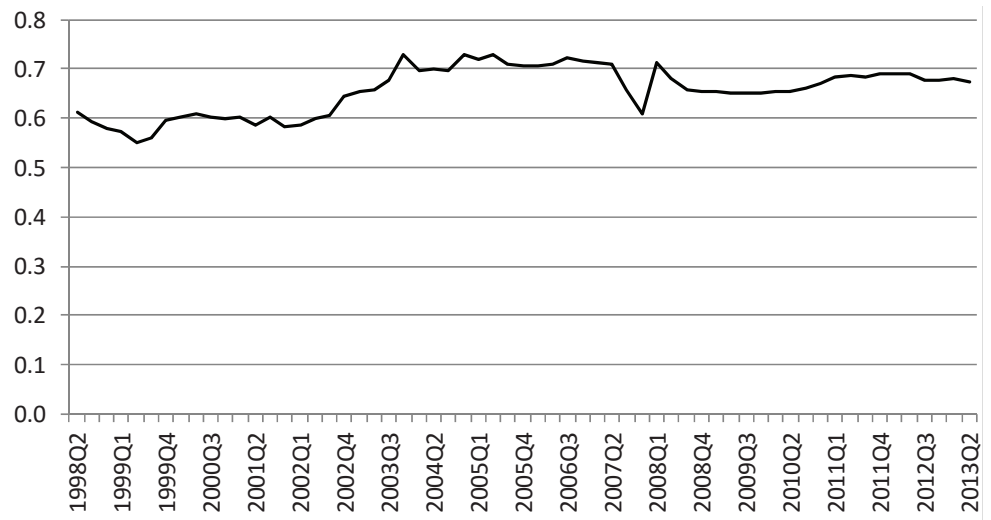

Source: CNBS. 
Figure 13

Honduras: Subsidiaries of Foreign Banks’ Herfindahl-Hirschman Index (In percent)

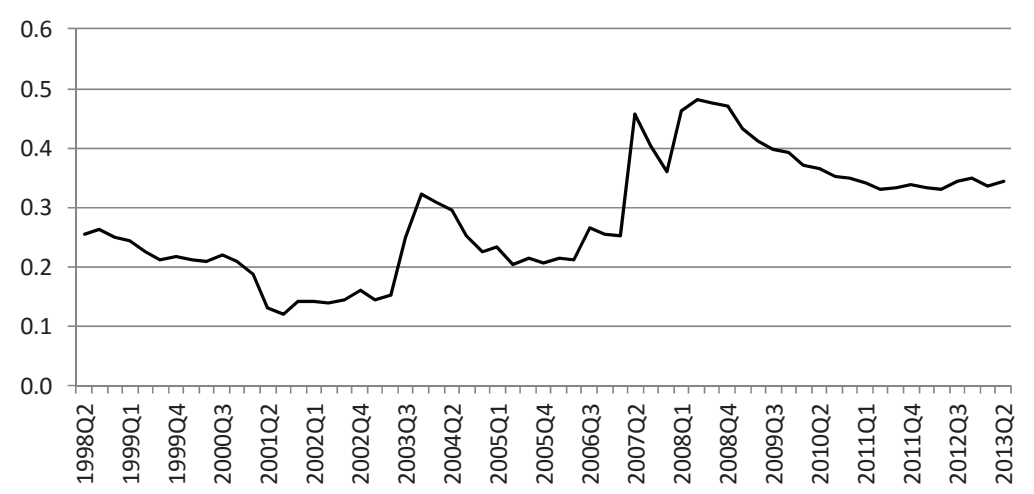

Source: CNBS.

\section{Figure 14}

Honduras: Locally Owned Banks’ Herfindahl-Hirschman Index (In percent)

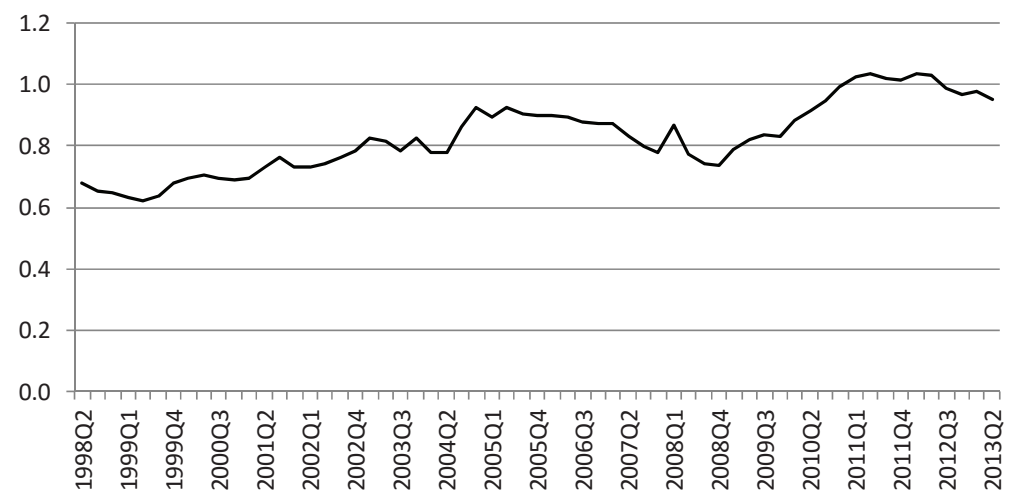

Source: CNBS.

\section{Figure 15}

Honduras: Banks' Credit-to-Deposit Ratio (Quarterly; in percent)

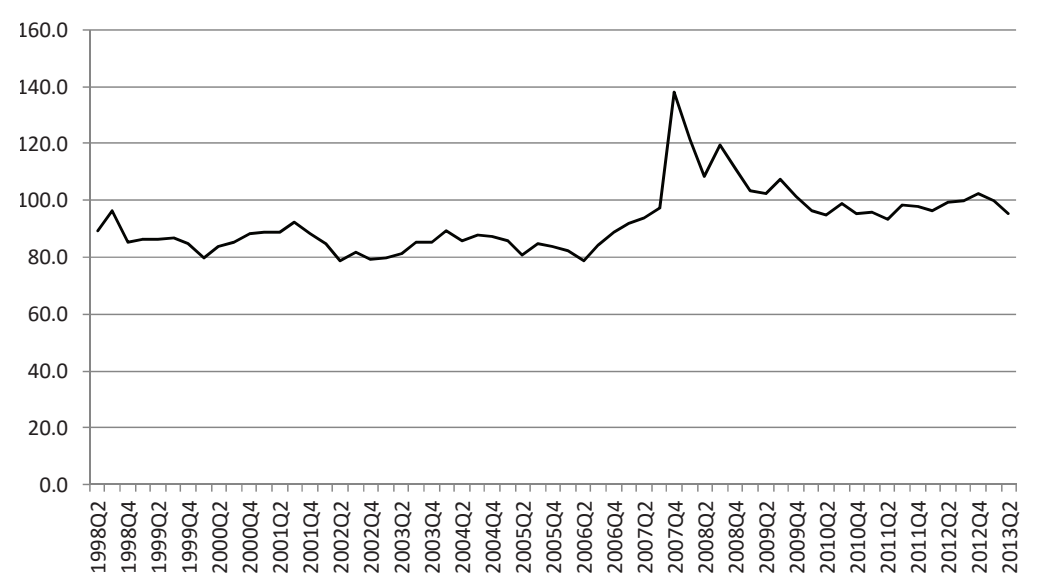

Source: CNBS. 
Figure 16

Honduras: Subsidiaries of Foreign Banks' Credit-to-Deposit Ratio (Quarterly; in percent)

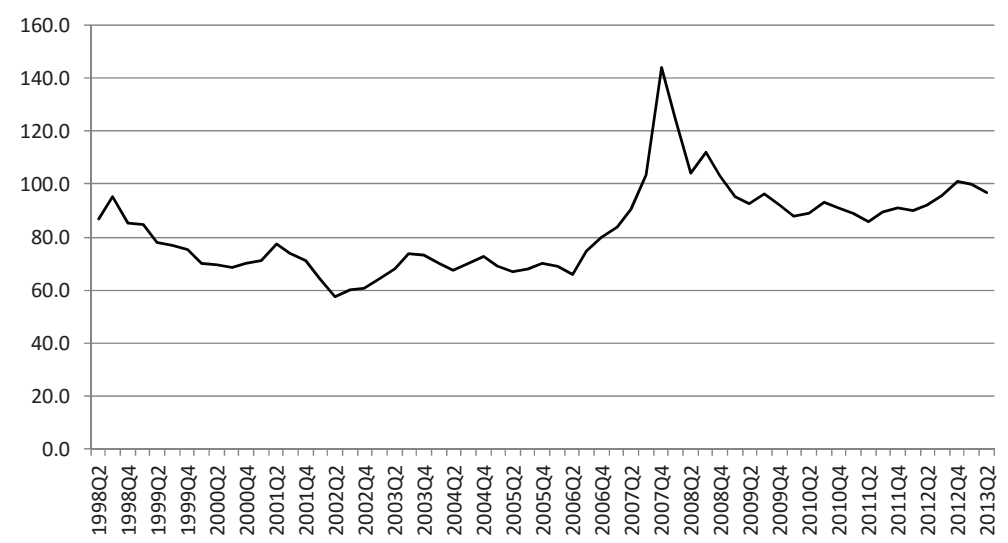

Source: CNBS.

\section{Figure 17}

Honduras: Locally Owned Banks' Credit-to-Deposit Ratio (Quarterly; in percent)

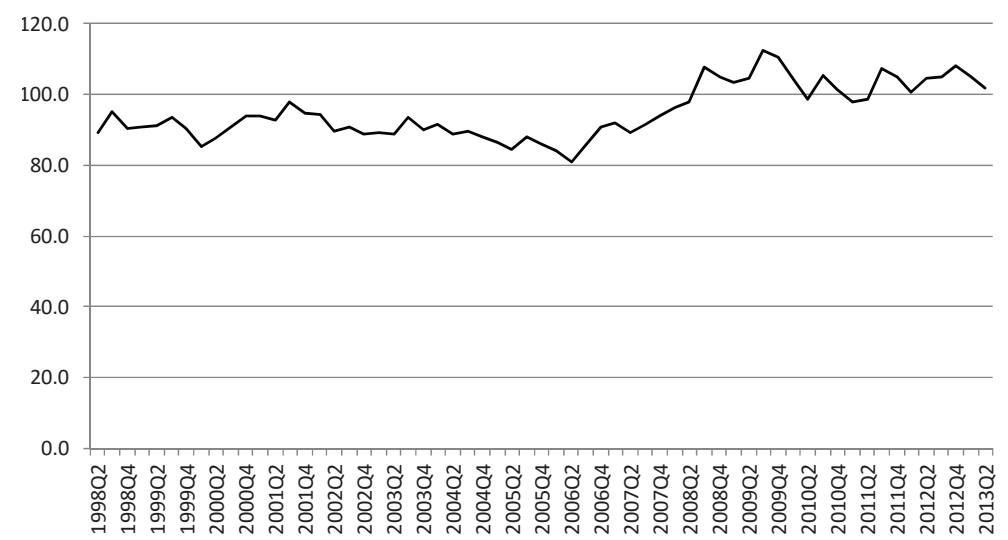

Source: CNBS

\section{Figure 18}

Honduras: Real GDP Growth (Quarterly; in percent)

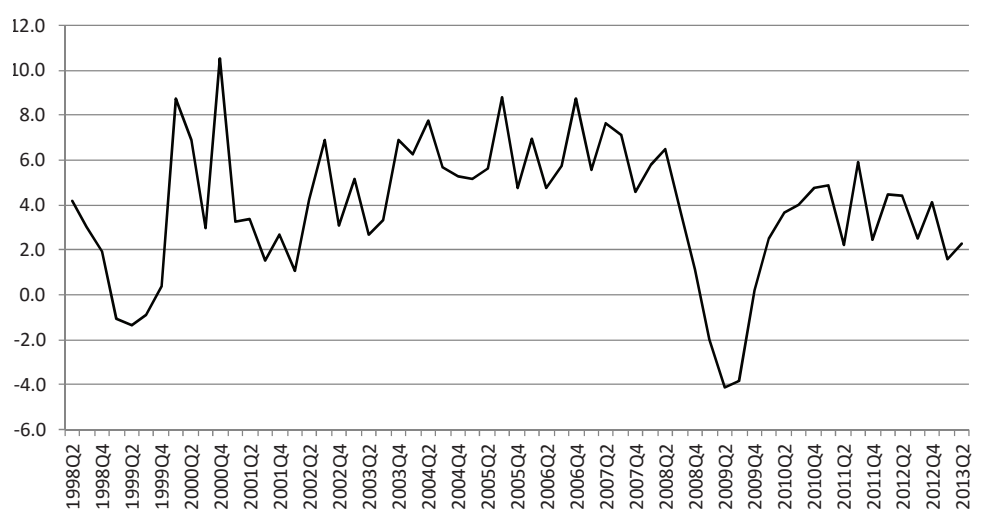

Source: CNBS 
Figure 19

Honduras: Inflation (Quarterly; In percent)

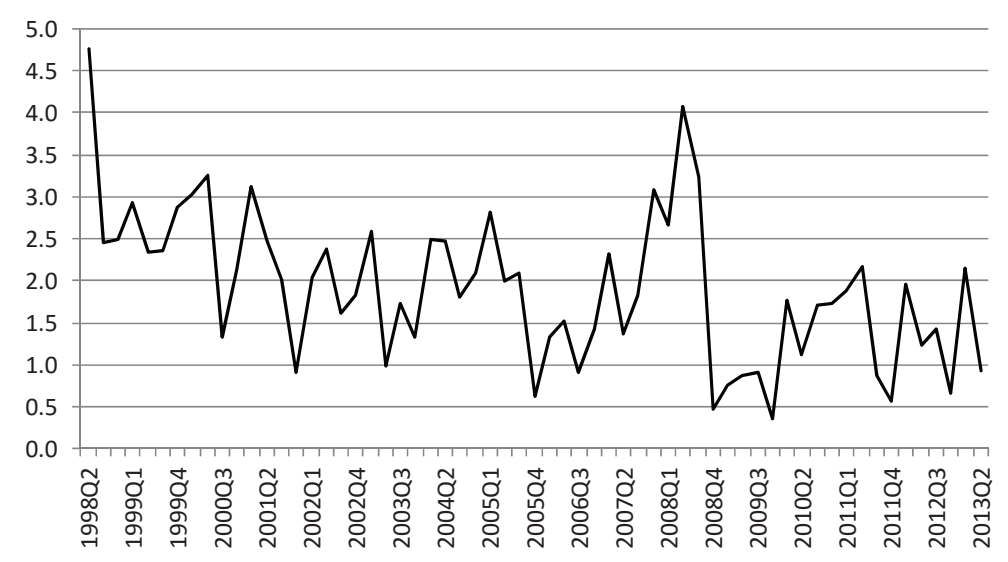

Source: CNBS. 